\title{
The Efficiency of Virtual Museum in Development of Grade Eight Students' Achievements and Attitudes towards Archaeology in Oman
}

\author{
Nada Ali Ambusaidi 1, Ahmed Hamad Al-Rabaani ${ }^{2}$
}

\section{ARTICLE INFO \\ Article History: \\ Received 01.02.2019 \\ Received in revised form \\ 22.05.2019 \\ Accepted \\ Available online 01.10.2019}

\begin{abstract}
This study investigates the effectiveness of using virtual museum in teaching social studies for the development of eighth grade students' achievement and attitudes towards archaeology. A quasiexperimental study was conducted with a sample of 60 females, comprising one experimental and one control group (each consisting of 30 students). The experimental group was taught by virtual museum, while the control group was taught by the traditional method. The data was collected by administering an achievement test with thirty questions and a 43-item attitudinal scale. The validity of these instruments was checked by a panel of judges and reliability was examined using Cronbach's alpha: (.712) for the test and (.891) for the scale. The results showed significant differences $(\alpha=0.05)$ between the means of the groups in favor of experimental groups in achievement test and attitudes towards archaeology and towards using museum in teaching. The study thus indicates that the use of virtual museums is beneficial in providing a supportive and encouraging learning environment.
\end{abstract}

(C) IJERE. All rights reserved

Keywords: ${ }^{1}$

Virtual museum, social studies, achievement, Oman, Grade eight students.

\section{INTRODUCTION}

Human history is reconstructed from physical and intellectual artefacts such as monuments and documents that are considered a fundamental element in teaching history. The use of physical artefacts is particularly useful to communicate history to the young. However, the preservation of such artefacts in museums to preserve and maintain them as invaluable cultural heritage has often barred the public from access and use of such cultural resources; even when schools can organize trips to visit museums (which is itself economically impossible in many contexts), there are often intrinsic barriers to the ways in which students can interact with potential learning resources in traditional museum contexts (George, 2010). Consequently, the modern development of immersive virtual reality and graphics technology, along with the increasing ubiquity and affordability of e-learning platforms, has led to the emergence of the concept of the virtual museum (VM), which fundamentally aims to enhance and improve the benefits of traditional museums by making them universally accessible to online users of all ages and cultures. VM was defined by Werner $(2004,3)$ as:

A connected group of digital entities consisting of various media that provide many communication points and linking centers, and allow giving up traditional ways of communication and interaction with visitors, as a digital symbolization for the exhibits, making it accessible from anywhere in the world.

The development of VMs has contributed to providing the educational field with a rich scientific resource to develop students' historical awareness. According to Joma'a (2012), history teachers, across many decades, have suffered from obtaining or being acquainted with historical documents, which passively affected the possible development of the students' knowledge of historical monuments, as well as the development of their historical thinking skills. Thus, the introducing of virtual measure has made a massive change in teaching history. Jones and Mark (2002) stated that the distinctive feature of development in the field of VMs is its use of the internet and HTML technology through which one can surf the internet on a PC, in addition to the variety of quality standards and applications of these museums. Some of these include simple texts and illustrations, while some have are more advanced multimedia, including cartoons, videos, voices synchronizing events, as well as user-friendly, attractive interfaces.

VMs enable visitors to access to exhibited monuments and interact with them in ways impossible with actual physical artefacts, as well as imparting background knowledge about historical context in a more

\footnotetext{
${ }^{1}$ Ministry of Education

Sultan Qaboss University, college of education - Omani studies Center, rabaani@hotmail.com ； https://orcid.org/0000-0002-1552-5016
} 
dynamic and engaging way (Christal et al., 2001; Sanda, 2012). This can result in greater learning engagement, motivating learners (i.e. visitors) to investigate and discover the whole picture of the studied events (Berthing \& Engquist, 2007). VMs can also be accessible at all times (i.e. 24/7), which enables visitors to access museums at any time they choose. They can facilitate tackling many problems related to Social Studies in general, and History in particular (Al-Salk, Ahmed \& Al-Ghannam, 2008). They allow social studies teachers to bring historical events to their classrooms and enable students to discuss these events.

The intrinsic advantages of using VMs in teaching were supported by the findings of some experimental studies showing the role of VMs in developing different learning skills, such as creative and innovative thinking, as well as the historical thinking skills. (Mohammed, 2000; Al-Salk, Ahmed \& AlGhannam, 2008). Also, the findings of some studies indicated the role of museums in developing students' archeological awareness (Petridis et al., 2004; Fredric, 2010; Joma'a, 2012). They have also been found to improve students' academic achievement (Stinson, 2001; Ulusoy, 2010; Okolo et al., 2011; Yildiri \& Tahdrogla, 2012), as well as to improve the learning environment process (Barajas, 2000; Michailidou \& Economides, 2003).

Based on these advantages of VMs, this paper explores a VM application to find solutions to several problems facing the teaching of history in Omani schools. Some of these problems related to a shortage of historical documents, materials and monuments referring to the events or achievements included in the curriculum. The shortage of such materials drives social studies teachers to mainly depend on textbooks and in some cases visit museums, but the latter is often limited due to logistical, budgetary and geographical barriers (i.e. the distance between regional schools and museums, which are concentrated in the capital, Muscat).

Based on that, the researchers decided to use VM to teach history in order to bring past events to the classroom. The VM was developed by the researchers including all needed historical documents and materials to teach history for eighth-grade students.

\section{Research Questions}

1. What is the efficiency of using the VM in developing achievement of Grade Eight students?

2. What are Grade Eight students' attitudes towards using the VM in teaching Social Studies?

3. What is the efficiency of using the VM in developing attitudes of Grade Eight students towards archeology?

\section{Aims}

The current study aims to achieve the following:

1. Measuring the efficiency of using the VM in developing achievement of Grade Eight students.

2. Measuring the efficiency of using the VM in developing attitudes of Grade Eight students towards using it.

3. Measuring the efficiency of using the VM in developing attitudes of Grade Eight students towards archeology.

\section{Methodolgy}

\section{Research Design}

This study adopts a quasi-experimental methodology to recognize the efficiency of VM in developing grade eight students' achievement and attitudes towards archeology, based on an experimental study of a control group receiving traditional teaching methods for Social Studies and the experimental group receiving VM in teaching, as shown in Table 1. 


\begin{tabular}{llll}
\hline \multicolumn{1}{c}{$\begin{array}{c}\text { Pre-test } \\
\text { application }\end{array}$} & Study group & \multicolumn{1}{c}{$\begin{array}{c}\text { Processing type } \\
(15 / 3-20 / 4 / 2016)\end{array}$} & \multicolumn{1}{c}{ Post-test application } \\
\hline $\begin{array}{l}\text { Achievement } \\
\text { test }\end{array}$ & Experimental & $\begin{array}{l}\text { Teaching the 'Omani Cities' } \\
\text { unit using VM }\end{array}$ & $\begin{array}{l}\text { Achievement test on the 'Omani Cities' unit } \\
\text { Measurement } \\
\begin{array}{l}\text { of attitude } \\
\text { towards } \\
\text { archeology }\end{array}\end{array}$ \\
\cline { 2 - 4 } & Control & $\begin{array}{l}\text { Teaching the 'Omani Cities' } \\
\text { unit using traditional teaching } \\
\text { methods }\end{array}$ & $\begin{array}{l}\text { Achievement test on 'Omani Cities' unit } \\
\text { Measuring attitudes towards archeology }\end{array}$ \\
\hline
\end{tabular}

\section{Sample}

The study sample consisted of (60) grade eight students selected from Al-Rumais Elementary School (for male and female children aged 6-12). It is an intentional sample, as the school is near the researchers' place of residence, and due to availability of all means of application, administrative and technical facilities required. The study sample was divided into experimental and control groups, each comprising 30 students. Table 2 shows the distribution of sample members in both groups.

Table 1: Group distribution

\begin{tabular}{ccccc}
\hline & Control group & \multicolumn{2}{c}{ Experimental group } & Total \\
\hline Class & Number & Class & Number & \\
\cline { 1 - 4 } $8 / 1$ & 30 & $8 / 4$ & 30 & 60 \\
\hline
\end{tabular}

\section{Equivalence of Both Groups}

Pre-test application was used to ensure the equivalence of the groups so that subsequent comparison was meaningful. Their results indicated that there was no statistically significant difference, as indicated in Table 3.

Table 2: Pre-test percentage of averages, measurement deviations, and (C) Value

\begin{tabular}{ccccccc}
\hline Group & Number & Average & $\begin{array}{c}\text { Measurement } \\
\text { Deviation }\end{array}$ & $\begin{array}{c}\text { Freedom } \\
\text { Degree }\end{array}$ & $\begin{array}{c}(\mathrm{C}) \\
\text { Value }\end{array}$ & $\begin{array}{c}\text { Significance } \\
\text { Level }\end{array}$ \\
\cline { 1 - 3 } Experimental & 30 & 5.30 & 2.80 & & & \\
\hline Control & 30 & 8.73 & 2.85 & 58 & .593 & $.619 *$ \\
\hline * There are no statistically significant differences at $(\alpha=0.05)$ level, Test Total Degree $=30$
\end{tabular}

\section{STUDY MATERIALS}

After reviewing a number of studies that discussed VMs, the researchers prepared the materials of the study as follows:

\section{Virtual Museum}

The researchers established a simplified VM about Unit 6 of grade eight textbook Omani Cities through following these steps:

- Collecting information, scientific material and historical documents serving the unit lessons from governmental institutions and obtaining publishing rights.

- Consulting the specialized and experienced staff members in the Technology Department about how to launch a VM via the internet. 
- Browsing and viewing a number of well-known VMs on the internet.

- Starting to design a VM based on some design programs. The museum contained several features supporting the enhancement of learning environment, such as illustrations, videos and a big library having a number of historical documents and parchments that can be used by teachers during explanation.

\section{Teacher Guide to Teach the Unit}

The researchers developed the teacher's guide to use in teaching the Omani Cities unit through VM. It includes lessons objectives, lessons materials and procedures of applying VM.

\section{Activities Notebook}

The researchers also developed an activities notebook including several activities related to each lesson in order to enhance learning environment.

\section{Achievement Test and Attitudes Scale}

An achievement test was developed that consisted of (30) questions. A five-point Likert scale was developed consisting of (43) items divided into four aspects: importance of VM in teaching social studies, attitudes towards the VM as learning tools, using VM and attitudes toward historical monuments.

\section{Validity and Reliability}

The validity of VM, teacher guide, activities notebooks, achievement test and a panel of judges examined the attitudes scale. The reliability of the achievement test and attitudes scale were examined by applying them in the pre-test. The reliability of the achievement test was (.728), while the reliability of the attitudes scale was (.891)

\section{Results and Discussion}

- What is the efficiency of using the VM in developing the achievement of Grade Eight female students in the subject of Social Studies?

Table 3: Pre- and post-test percentage of averages, measurement deviations, and (C) Value

\begin{tabular}{|c|c|c|c|c|c|c|}
\hline Test & Groups & Mean & SD & df & $\mathrm{t}$ & sig \\
\hline \multirow[t]{2}{*}{ Pre-application } & Experimental & 8.30 & 2.80 & \multirow[b]{2}{*}{58} & .593 & \multirow[t]{2}{*}{.619} \\
\hline & Control & 8.73 & 2.85 & & & \\
\hline \multirow[t]{2}{*}{ Post-application } & Experimental & 28.06 & 2.09 & \multirow[t]{2}{*}{58} & \multirow[t]{2}{*}{16.821} & \multirow[t]{2}{*}{$0.000 *$} \\
\hline & Control & 15.80 & 3.39 & & & \\
\hline
\end{tabular}

The results showed that there were significant differences between the control and experimental groups in favor of the latter, which was clearly obvious where the experimental group achievement in the pre-test was (8.30) of a total of 30 while in the post test they achieved (28.06); in contrast, the control group achieved (8.70) and (15.80) respectively. These results indicate the effectiveness of VM in developing students' achievement in the social studies subject.

The researchers attribute this result to the characteristics of VM, which makes it an efficient educational means through its ability to create an active and attractive learning environment. The museum included a number of 3D photos and videos enhancing the explanation of events. The VM particularly encouraged females to think deeply in the events presented, and drove them to search for more information. Also, the variety of classroom activities when using the $\mathrm{VM}$ enables students to evaluate themselves and to be 
concerned with acquiring knowledge and skills (i.e. increased learner autonomy). The VM enhances students' involvement in discussion and introducing their views without any kind of hesitation. Moreover, the inclusion of information in the museums with different illustrations enabled females to understand the information easily and drove them to be more enthusiastic to search for more information through the web.

The use of the VM made teaching historical events makes it easier and more attractive to learn about them. Female students showed higher interest to share information with their colleagues and try to go deeper in analyzing and describing historical events. These results are in line with those of previous studies which showed the effectiveness of VM in the development of students' achievement (Stinson, 2001; Watson et al., 2007; Yildirim \& Tahdroglu, 2012).

- What are the attitudes of elementary Grade Eight Students towards using the VM in teaching the subject of Social Studies?

Table 4: Attitudes towards the efficiency of using VM in Social Studies learning

\begin{tabular}{lccl}
\hline \multicolumn{1}{c}{ Domains of the scale } & Mean & SD & Level \\
\hline The importance of VMs in teaching Social Studies & 4.73 & .238 & Highly Positive \\
\hline Attitude towards VM, as a learning method & 4.72 & .220 & Highly Positive \\
\hline Dealing with the VM & 4.72 & .265 & Highly Positive \\
\hline General attitude & 4.72 & .241 & Highly Positive \\
\hline
\end{tabular}

It can be noted from the table that female students showed highly positive attitudes toward using VM in learning Social Studies and as a learning method generally, and they viewed dealing with the VM positively. Such results are attributable to several reasons including changes in the learning environment whereby VM is novel, dynamic and more exciting that traditional, textbook-based teaching methods. It also due to the ability of VM to bring historical events to the classroom as living experiences with which they can relate, which motivates female students to be more interested in gaining information. Also, the inclusion of several activities in VM encourages students to be more active and interact with their colleagues and teachers.

These results could also be attributed to the inclusion of multimedia resources to enhance students' ability to understand historical events in easy way and come up with a comprehensive understanding. Also, the communication feature with the VM enables students to easily communicate with their teachers and colleagues in different times, to get feedback and to receive answers for their questions. Another reason for such results could be due to that the VM includes icon for 'star of the week' awards that could motivate students to be more active in seeking the award. Previous studies have indicated that using VM enhances teaching (Ismail, 2009), and replicates the positive academic features of the traditional museum in a more engaging format with improved student interaction (Katz \& Halpern, 2015). Castle (2004) also showed that VM enhances communication between different parties, whereby female students have open opportunities to communicate with their teacher and their colleagues in an easier and more flexible manner. The results also support Prosser and Eddisfored (2004), who showed higher positive attitudes towards using VM in teaching.

- What is the efficiency of using the VM in developing the attitudes of Grade Eight students towards historical monuments? 
Table 5: Attitudes towards historical monuments

\begin{tabular}{|c|c|c|c|c|c|c|}
\hline & Group & Mean & $\mathrm{SD}$ & df & $\mathrm{t}$ & sig \\
\hline \multirow{2}{*}{ Pre-application } & Control & 3.98 & .307 & \multirow[b]{2}{*}{58} & .745 & \multirow[b]{2}{*}{.459} \\
\hline & Experimental & 3.91 & .406 & & & \\
\hline \multirow{2}{*}{ Post-application } & Control & 4.19 & ,609 & \multirow[b]{2}{*}{58} & 3.402 & \multirow[b]{2}{*}{$* .001$} \\
\hline & Experimental & 4.67 & .473 & & & \\
\hline
\end{tabular}

There is a statistically significant difference at the level $(\alpha=0.05)$ Total Degree of the Test $=30$

The results shown in the previous table indicate significant differences between the control and experimental groups, with much improved attitudes towards monuments among the latter. This could be due to the greater engagement the experimental group had with monuments due to the facilitation of VM, which enabled them to obtain a more meaningful connection and deeper insight, gaining more related information such as the reasons for their construction, the eras in which they were built and the nature of the societies who built them, among other information. Also, VM drove students to ask questions and be more concerned about searching for information to get a more comprehensive understanding of the monuments. According to Joma'a (2012), such information gives a positive impression to the students towards the particular historical artefacts and contexts being studies, as well as towards the history-related disciplines generally.

Also the VM encourage the female students to raise questions stimulating thinking in relation to the valuable treasure of different and various monuments of the Sultanate of Oman Sultanate, which can promote citizenship values in addition to increasing awareness of the intrinsic cultural worth of citadels and castles in protecting the security and safety of the Sultanate throughout history as well as manifesting the technical, economic and social values of Omani society, as well as comparing different uses of such monuments in the past and the present. This is in harmony with what is referred to in the literature about $\mathrm{VM}$ in transporting learners from their own immediate context to worlds imitating nature to complete the educational role, and through which the student is transferred to an immersive learning environment quite similar to reality (Schweibenz, 1998; Al-Salk, Ahmed \& Al-Ghannam, 2009; Yildirim \& Tahroglu, 2014).

The VM also contributed to forming a live image about some monuments or historical landmarks in Oman, visualizing them through the 3D photos or exhibited videos, or even through some activities inside or outside class. Therefore, learners were acquainted with most monuments that they had never seen before, as well as the simple appreciation of monumental pieces from a long and glorious past. Thus, they gained a knowledge base on the most important landmarks in Oman and differentiated among them. Furthermore, they knew the locations of these historical places. Thus, abstract historical and civic concepts became more tangible to their minds, and their awareness and understanding of some archeological terms was consequently improved.

One of the advantages that strengthened this result is the ability of the VMs to exhibit the biggest possible amount of information, in a given and organized time schedule, so students can distinguish the historical period to which each monument belongs, which makes it easier for them to link the historical events with each other, and understand the historical sequence of these historical monuments in reality (Mousa \& Khalaf, 2008; Ismail, 2009; Joma'a, 2012) This is actually what the VM achieved, particularly after exhibiting an identification card for each Omani city mentioned in the unit, stating its most important monuments, the era to which they belong, as well as the notable role they played in history. These features fostered positive attitudes of the students towards historical places, particularly monumental landmarks of national importance, whether in ancient or modern times, in addition to the historical texts and documents exhibited concerning notable episodes from Omani history, in relation to which learners appraised the historic role of Oman or its heritage capabilities. These features fortify the value of these monuments in the students' minds. 
Ambusaidi,N.A. \& Al-Rabaani,A.H. (2019). The efficiency of virtual museum in development of grade eight students' achievements and attitudes towards archaeology in Oman. International Journal of Educational Research Review,4(4),496-503.

\section{Conclusion}

The current study investigated the effectiveness of using VM on teaching social studies in the development of eighth grade students' achievement and attitudes towards the history and archaeology of Oman, with particular regard to monumental artefacts. It was found that the VM strongly affects students' achievement and attitudes.

\section{Recommendations}

In the light of the results shown by this study, the following recommendations are made:

1. Endeavoring to promote the use of the VM in schools in general, and in Social Studies in particular, as the field needs it to increase the school achievement.

2. Encouraging Social Studies teachers to use the VM, for the multimedia and the several capabilities it has which makes it an active educational environment.

3. Developing a conceptualization for parents about VM and its objectives through simplified explanatory booklets; to enable students to use it, and participate in extra-curricular activities (while staying at home).

4. Enabling teachers to participate in $\mathrm{VM}$ on a regular basis, with different activities and topics, so that its design is characterized by renewability and effective participation from educators.

\section{Acknowledgment}

We would like to thank all students who participated in this study and the school administration, who were very cooperative.

\section{References}

Al-Salk, D., Ahmed, M \& Al-Ghannam, E. (2008). The influence of relationship between ways of presenting photographer and roaming in developing of knowledge about development of educational learning equipment, Education Technology, 18(3) 145-152.

Barajas, M. (2002). Implementation of virtual environments in training and education. Final Report of European Commission Project Contract Nº: SOE2-CT98-2037. European Commission. Retrieved 1 November 2015 from: http://goo.gl/rb39xR

Berthing, J. \& Engquist, A. (2007). Transcending the boundaries of the museum: Managing organizational change in the museum and web. Retrieved 1 November 2015 from: http://www.museumsandtheweb.com/mw2007/papers/berthling/berthling.html

Castle, C. (2004). Teaching in the virtual museum. Presented at the Ontario Museum Association's Colloquium on Learning in Museums VII, Peterborough, Ontario, October 20, 2004. Retrieved 1 January 2016 from: http://www.mccastle.com/UserData/OMA04_Teaching_in_the_virtual_museum.pdf

Christal, M., Montano, M. D., Resta, P., \& Roy, L. (2001). Virtual museums from four directions: An emerging model for school-museum collaboration. In C. Montgomerie \& J. Viteli (Eds.), Proceedings of EdMedia: World Conference on Educational Media and Technology 2001 (289-294). Association for the Advancement of Computing in Education (AACE).

Fredric, R. (2010). Using online field trips and tours in social studies. Social Education Magazine, 3(74), 137-138. https://goo.gl/p774Cz

George. E. (2010). The role of museums in society: education and social action, The Museum Journal, 48(4) 357486 
Ambusaidi,N.A. \& Al-Rabaani,A.H. (2019). The efficiency of virtual museum in development of grade eight students' achievements and attitudes towards archaeology in Oman. International Journal of Educational Research Review,4(4),496-503.

Ismail, D. (2009) Educational virtual museum. Cairo, Egypt: Alam Al-Kitab

Joma'a, A. (2012). Effectiveness of online museum in development of first preparatory students archeology awareness, Education Association Journal of Social Studies, 14,27-38

Katz, J., \& Halpern, H. (2015). Can virtual museums motivate students? Toward a constructivist learning approach. Journal of Science Education and Technology, 24(6), 776-788.

Michailidou, A., \& Economides, A (2003). E-learn: Towards a collaborative educational virtual environment. Journal of Information Technology Education, 2, 131-152. Retrieved 22 January 2016 from: http://goo.gl/f7uFxx.

Mohammed, A. (2000). Effectiveness of suggested unit about historical forts and fortress through virtual museum. Studies in Curriculum \& Instruction, 64, 98-118.

Mousa, S., \& Khalaf, A. (2008) Library and museum education for KG students. Cairo, Egypt: Alam Al-Kitab.

Okolo, C. M., Englert, C. S., Bouck, E. C., Heutsche, An., Wang, H. (2011). The virtual history museum: Learning U.S. history in diverse eighth grade classrooms. Remedial \& Special Education, 5(32), 417-428.

Petridis, P., White, M., Mourkousis, N., \& Gatzidis, C. (2005). Exploring and interacting with virtual museum. University of Sussex, Department of Informatics. Retrieved 1 November 2015 from: http://www.fi.muni.cz/ liarokap/publications/CAA2005.pdf

Prosser, D., \& Eddisofr, S. (2004). Virtual museum learning: Information technology in childhood education annual. International Journal on E-Learning, 2(1), 14-20.

Sanda, S. (2012). Audio guided virtual museums. University of Sarajevo. Retrieved 1 November 2015 from: http://goo.gl/jENIAA

Schweibenz, W. (1998). The "Virtual Museum": New perspectives for museums to present objects and information using the internet as a knowledge base and communication system. In H. H. Zimmermann \& V. Schramm (Eds.), Knowledge Management und Kommunikationssysteme, Workflow Management, Multimedia,

Knowledge Transfer: Proceedings des 6. Internationalen Symposiums für Informationswissenschaft (ISI 1998) (185-200), Prague, 3-7 November 1998. Konstanz: UVK Verlagsgesellschaft. Retrieved 1 November 2015 from

Stinson, S. (2001). The effect of a web-based museum tour on the social studies achievement of fifth grade students. Ed. D. thesis, University of Houston.

Ulusoy, K. (2010). Open education students' perspectives on using virtual museum application in teaching history subjects. Turkish Online Journal of Distance Education, 11(4), 36-46.

Watson, S., Dodd, J., \& Jones, C. (2007). Engage, learn, achieve: The impact of museum visits on the attainment of secondary pupils in the East of England 2006-2007. Leicester, UK: Leicester University, Research Centre for Museums and Galleries. http://soo.gd/AJgM

Werner, S. (2004). The development of virtual museum. International Council of Museums News, 3, 3. Retrieved 1

November 2015 from http://www.icom.museum/fileadmin/user_upload/pdf/ICOM_News/2004-

3/ENG/p3_2004-3.pdf

Yildirim, T., \& Tahdroglu, M. (2012). The effects of virtual museum visits of elementary students' attitudes. Electronic Journal of Social Sciences, 11(39), 104-114. 